\title{
Characterization of genes, down-regulated in human glioma, potential tumour suppressor genes
}

\author{
V. V. Dmitrenko, O. I. Boyko, K. O. Shostak, N. Ya. Vitak, T. V. Bukreeva, V. D. \\ Rozumenko', T. A. Malysheva ${ }^{1}$, M. I. Shamayev ${ }^{1}$, Yu. P. Zozulya ${ }^{1}$, V. M. Kavsan
}

The Institute of Molecular Biology and Genetics 150 Zabolotny Str., Kyiv, 03143, Ukraine

${ }^{1}$ The Institute of Neurosurgery named after Romodanov A.P., Academy of Medical Sciences of Ukraine 32 Manuylsky Str., Kyiv

dmitrenko@imbg.org.ua

\begin{abstract}
Comparison of gene expression profiles in human normal brain and glioblastoma using SAGE database re-

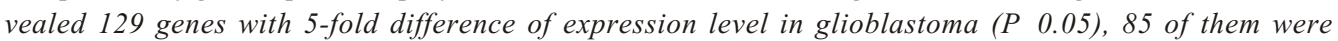
down-regulated. The number of genes with 5-fold down-regulated expression is less in the diffuse and anaplastic astrocytomas. Five-fold decrease of the expression in the diffuse astrocytoma and nearly the same expression levels in the anaplastic astrocytoma and glioblastoma were revealed for 9 genes only. For overwhelming majority of inactivated genes in the low-grade astrocytoma the expression level decreased progressively in the subsequent stages of malignant progression of astrocytoma. Expression levels of some genes were very low or undetectable in glioblastoma, the most aggressive brain tumour. The decreased expression of selected genes in glioblastoma was confirmed by Northern analysis and RT-PCR. Some genes, described in this work, may encode the tumour suppressors and their decreased expression may play an important role in initiation and progression of human glioma.
\end{abstract}

Keywords: glioma, astrocytoma, glioblastoma, down-regulated genes, potential tumour suppressors

Introduction. Several methods for the identification of differential gene expression have been developed. These methods include two most powerful technologies, hybridization of DNA-microchips and Serial Analysis of Gene Expression (SAGE), which revolutionised biomedical research in determining the roles

\footnotetext{
(C) V. V. DMITRENKO, O. I. BOYKO, K. O. SHOSTAK, N. YA. VITAK, T. V. BUKREEVA, V. D. ROZUMENKO, T. A. MALYSHEVA, M. I. SHAMAYEV, YU. P. ZOZULYA, V. M. KAVSAN, 2007
}

of genes in various pathologies, particularly during the tumour process. Gene expression patterns and the information on genes, differentially expressed in various tumours, obtained by modern multi-factor analysis, enables the use of the combinations of identified genes for determination of specific tumour type within current tumour category, improving the diagnostics, and determining justified criteria of treatment choice for each patient [1]. The availability of early diagnostic markers would decrease sig- 
nificantly the incidence of tumour diseases and the mortality rate. The application of SAGE in the previous publications allowed us to investigate and characterise the genes with significantly increased expression level in glioblastomas [2, 3]. Comparative analysis of SAGE-libraries of astrocytomas of malignancy grades II-IV and human normal brain (NB) revealed the number of genes, the expression of which increases or decreases in tumours cells, to increase in the course of malignant progression. Current work attempts to characterise the genes with decreased level of expression in astrocytic tumours.

Materials and Methods. 9 SAGE libraries of glioblastomas (malignancy grade IV astrocytomas according WHO classification), 11 SAGE libraries of anaplastic astrocytomas (malignancy grade III astrocytomas), 8 SAGE libraries of diffuse astrocytomas (malignancy grade II astrocytomas), and 5 NB SAGE libraries have been analysed in order to compare the expression of genes using Digital Gene Expression Displayer (DGED) software and databases of SAGE Genie web-site (http://cgap.nci.nih.gov/SAGE). Unigene database (National Center of Biotechnological Information, $\mathrm{NCBI}$ ) was used to search for cDNA clones, containing encoding regions of mRNA. Selected cDNA clones were obtained from Resource Centre/Primary DataBase, RZPD, of Human Genome Project, Germany. Surgical samples of glial tumours and NB (histologically normal brain tissue, adjacent to the tumour, compulsorily ablated with the tumour during the operation) were immediately frozen after resection in liquid nitrogen and stored at $-70^{\circ} \mathrm{C}$.

Total RNA was extracted from frozen tissues by acidic guanidine isothiocyanate-phenol-chloroform solution [4] and analysed by Northern hybridisation, as described in $[2,3]$. Densitometric analysis of hybridisation signals was performed using Scion Image 1.62c software.

cDNAs were synthesised with oligo(dT) primer and reverse transcriptase (RT) RevertAid (Fermentas, Lithuania) using the same amount of total RNA (10 $\mu \mathrm{g}$ for each sample). Semi-quantitative polymerase chain reaction (PCR) was performed according to Rae et al. [5] in $20 \mu \mathrm{l}$ of the reaction mixture, containing cDNA, synthesised on $0.5 \mu \mathrm{g}$ of RNA, 2 units of Taq-polymerases
1xPCR buffer, $0.2 \mathrm{mM}$ dNTPs, and $1 \mu \mathrm{M}$ primers for corresponding genes:

CPNE6 (for TGTCCCACCTGCACACGTTTG, rev CGTGTCATTCACCACTTGGGG);

DRDIIP (for CAGCAGAATTTCCCTGACCTGG, rev ACGCGCTGGTCACAGGAGCTG);

FAT2 (for GGAAGGAAGGAACTAATTCTTC, rev CTCTACACATGTGTACACACG);

GRIN1 (for TTCGGCATAGGCATGCGCAAAG, rev CACAGACAAGGCGCCCGTTAG);

GRM4 (for GTACACCACTTGCATCGTCTGG, rev ACGCAGGTTCTTGTGGTAGCCT);

SLC12A5 (for CATCAAGGACTCATCAAGGACT, rev AACTGGCACTGAGGAGCTCTGG).

PCR was performed with the following parameters: denaturation at $94^{\circ} \mathrm{C}, 30 \mathrm{sec}$; annealing at the temperature, corresponding to each of the primer pairs, $1 \mathrm{~min}$; synthesis $-72^{\circ} \mathrm{C}, 1 \mathrm{~min}(30$ cycles $)$ and $72^{\circ} \mathrm{C}, 7 \mathrm{~min}$. The number of cycles was gradually decreased till amplification of PCR-product remained at the level of linear phase (27 cycles). PCR products were detected with ethidium bromide staining after electrophoresis in $2 \%$ agarose gel.

Results and Discussion. To compare the relative levels of gene expression in astrocytomas of different malignancy grades and NB by SAGE we used public database of Cancer Genome Anatomy Project. Using DGED option, expression change ratio was set to be 5 for the increase or decrease in the level of expression of each gene, while statistical probability was $\mathrm{P} \leq 0.05$. The comparison of 9 glioblastoma SAGE libraries and $5 \mathrm{NB}$ SAGE libraries revealed 199 gene tags with 5-fold difference in their distribution in these two pools [2]. In case when more than one tag matched one gene, the most probable one was selected. Five-fold changes in expression of 129 genes were detected upon deletion of tags for non-characterised expressed nucleotide sequences, tags without nucleotide sequences in Unigene clusters, tags of mitochondrial genes, and genes encoding hypothetic proteins. 85 genes matched the criteria of overexpressed in NB or of potential tumour-suppressor genes. Table $1,7^{\text {th }}$ column shows the correlation between the number of tags in all investigated SAGE-libraries of glioblastomas and number of those in all of NB. As it is seen, gene expression decreased more than 10 -fold in the vast majority of cases. 
Our investigation was based on 9 glioblastoma SAGE-libraries and 5 NB SAGE-libraries present in SAGE Genie database. Certainly, the expansion of the number of libraries may lead to the changes in the pattern of differential expression of genes. However, the comparison of the results obtained in this work with the results of the comparison of 5 glioblastoma SAGE libraries and 2 NB SAGE libraries [6] revealed the majority of 117 genes, identified in the aforementioned work, to be included into the present list of 129 genes [2].

The comparison of the pools of 11 anaplastic astrocytoma SAGE libraries and 8 astrocytoma SAGE libraries with the pool $5 \mathrm{NB}$ SAGE libraries at equal conditions of analysis, revealed the total number of tags with 5-fold distribution difference to be slightly lower than in the case of comparison of glioblastomas and NB -118 and 83 tags, respectively. The processing of data revealed 66 genes with 5-fold difference of expression level in anaplastic astrocytomas, 48 of which were of decreased expression, and 42 genes with 5-fold difference of expression level in astrocytomas, 26 of which were of decreased level of expression. Therefore, the number of genes with significant decrease of expression level increases throughout astrocytic glioma development.

There are two critical questions in modern investigation - what is the threshold in gene expression after which the changes can be considered significant and trustworthy and what are diagnostic, pathophysiological, and therapeutic consequences of the mentioned changes? Till there is no univalent answer for the latter question, every research group makes its own decision. For example, Lal et al. [7] described the genes with more than 5-fold expression with $\mathrm{P}<0.001$ analysing the differential expression of genes in glioblastomas and NB by SAGE; Loging et al. [1] used the same approach to analyse the genes with more than 10-fold changes in expression; Markert et al. [8] and Ljubimova et al. [9], as well as some other researchers, discussed the possible role of genes even with less than 2-fold expression change in the initiation and progression of tumours. Definitely, lowering the threshold allows identifying a greater number of differentially expressed genes, although the vast majority of genes with significant changes in expression are possibly more important biologically-wise.

The comparison of lists of genes with 5-fold decreased expression in astrocytomas revealed some expression changes to be at the same level throughout the development of astrocytomas, although significant decrease of expression level of most of the genes occur during the later, the most malignant, stages of tumour development. Thus, the level of expression of $C A 11$, DLG4, EEF1A2, RPH3A, MICAL2, EPHB6, NRIP3, and TTR (Table 2, group I) decreased in diffuse astrocytomas and remained relatively the same during the next stages of astrocytomas development, yet tags of FAT2 (FAT tumour suppressor homolog 2 (Drosophila)) is present in neither one of SAGE-libraries of astrocytomas of malignancy grades II-IV. At the same time, the expression levels of 31 genes (Table 2, group II) decrease more than 5-fold in diffuse astrocytomas, and, furthermore decreases during the following stages of astrocytoma development. Some genes (CPNE6, KCNQ2, GALNT9, SLC1A6, GRM4, FSTL5, NEUROD1) terminate their expression in glioblastomas, which is evident from Table 1. The decrease in the level of expression of 35 genes drops down more than 5-fold in glioblastomas only (Table 2, group III). The level of expression of 10 genes (Table 2, group IV) varies at different stages of astrocytoma development - in anaplastic astrocytomas (for ZIC4 and SYT5 in glioblastomas as well) level of expression is higher, compared to astrocytomas.

Northern analysis of individual independent tumour samples is the most applicable and the most reliable method to confirm the result of the comparison of gene expression profiles. Northern hybridisation of randomly selected genes generally confirmed the results of SAGE. Fig.1 shows high expression levels of $D N M 1$ and $N R G N$ in the majority of NB samples, however, their mRNA contents in glioblastomas is significantly lower, if any at all. A high content of $M B P$ mRNA was observed in NB and was detected to be much lower in astrocytic gliomas of malignancy grades II-IV; in glioblastomas this mRNA was not detected at all (Fig.2). SAGE results for SNAP25 and STXBP1 were not confirmed by Northern hybridisation SNAP25 is expressed at a high level in both NB and astrocytomas of malignancy grades II-IV, while 
Table 1

The list of genes with decreased expression level in glioblastoma, compared to normal human brain (NB)

\begin{tabular}{|c|c|c|c|c|c|c|c|c|c|}
\hline $\mathrm{N}^{\circ}$. & Tag & Gene name & $\begin{array}{c}\text { Gene } \\
\text { symbol }\end{array}$ & \multicolumn{2}{|c|}{ Libraries } & \multicolumn{2}{|c|}{ Tags } & $\begin{array}{c}\text { Tag } \\
\text { Odds } \\
\mathrm{A}: \mathrm{B} \\
\end{array}$ & $\mathrm{P}$ \\
\hline 1 & TGGGAAGTGG & Maternally expressed 3 & MEG3 & 7 & 5 & 70 & 163 & 0,15 & 0,04 \\
\hline 2 & CCСCCAATTC & $\begin{array}{l}\text { Vesicle-associated membrane protein } 2 \\
\text { (synaptobrevin 2) }\end{array}$ & $V A M P 2$ & 8 & 5 & 63 & 158 & 0,14 & 0,01 \\
\hline 5 & CGGGGAGATG & NDRG family member 2 & $N D R G 2$ & 7 & 5 & 43 & 118 & 0,12 & 0,01 \\
\hline 6 & ATTAAAGTCA & Regulating synaptic membrane exocytosis 3 & RIMS3 & 7 & 5 & 21 & 65 & 0,11 & 0,04 \\
\hline 7 & GTTTAAAAAG & Stathmin-like 2 & STMN2 & 8 & 5 & 21 & 63 & 0,11 & 0,05 \\
\hline 8 & TGGACACTCA & Neurochondrin & $N C D N$ & 9 & 5 & 81 & 252 & 0,11 & 0,00 \\
\hline 9 & ATCCGTGCCC & Calmodulin 3 (phosphorylase kinase, delta) & CALM3 & 8 & 5 & 28 & 106 & 0,09 & 0,00 \\
\hline 13 & АТСССТTССС & Septin 5 & SEPT5 & 7 & 5 & 16 & 69 & 0,08 & 0,00 \\
\hline 14 & CTTCAGGACC & Syntaxin binding protein 1 & $S T X B P 1$ & 8 & 5 & 24 & 104 & 0,08 & 0,00 \\
\hline 15 & TAATATTAAA & Synaptosomal-associated protein, $25 \mathrm{kDa}$ & $S N A P 25$ & 5 & 5 & 25 & 104 & 0,08 & 0,00 \\
\hline 16 & TCTGCACCTC & Eukaryotic translation elongation factor 1 alpha 2 & EEF $1 A 2$ & 8 & 5 & 44 & 184 & 0,08 & 0,00 \\
\hline 17 & TGCCCAAATG & Leucine-rich repeat LGI family, member 3 & $L G I 3$ & 4 & 5 & 10 & 42 & 0,08 & 0,03 \\
\hline 18 & TGGGACGTGA & $\underline{\text { EPHB6 }}$ & EPHB6 & 6 & 3 & 9 & 41 & 0,08 & 0,02 \\
\hline 19 & AAAGGGAATG & $\begin{array}{l}\text { Solute carrier family } 17 \text { (sodium-dependent } \\
\text { inorganic phosphate cotransporter), member } 7\end{array}$ & $S L C 17 A 7$ & 2 & 4 & 21 & 100 & 0,07 & 0,00 \\
\hline 20 & СTCTGGCTCT & Secretory carrier membrane protein 5 & SCAMP5 & 6 & 5 & 10 & 48 & 0,07 & 0,01 \\
\hline 21 & GAATTTGGGA & Junctophilin 4 & JPH4 & 4 & 5 & 9 & 44 & 0,07 & 0,01 \\
\hline 22 & AATAAAGCTA & Synuclein, beta & $S N C B$ & 6 & 5 & 21 & 128 & 0,06 & 0,00 \\
\hline 23 & AGAATACCTT & $\begin{array}{l}\text { Sparc/osteonectin , cwcv and kazal-like domains } \\
\text { proteoglycan (testican) }\end{array}$ & $S P O C K$ & 2 & 5 & 6 & 34 & 0,06 & 0,02 \\
\hline 31 & TCTGTGACCT & Flavoprotein oxidoreductase MICAL2 & $M I C A L 2$ & 5 & 4 & 7 & 38 & 0,06 & 0,02 \\
\hline 32 & TGTAACAATA & Neuritis with brachial prediliction & $N A P B$ & 5 & 5 & 14 & 79 & 0,06 & 0,00 \\
\hline 33 & TTCCCGGAAA & Sulfotransferase family $4 \mathrm{~A}$, member 1 & SULT4A1 & 3 & 5 & 6 & 32 & 0,06 & 0,04 \\
\hline 34 & TTCCGACTGC & Synaptogyrin 3 & SYNGR3 & 4 & 5 & 5 & 31 & 0,06 & 0,03 \\
\hline 35 & CACAACCACC & Rabphilin 3A homolog (mouse) & RPH3A & 5 & 5 & 6 & 41 & 0,05 & 0,00 \\
\hline 36 & CGGCTGCCCA & $\begin{array}{l}\text { Synuclein, gamma (breast cancer-specific } \\
\text { protein 1) }\end{array}$ & $S N C G$ & 6 & 5 & 7 & 48 & 0,05 & 0,00 \\
\hline 37 & GAGGCTGGAA & $\begin{array}{l}\text { Glutamate receptor, ionotropic, N-methyl } \\
\text { D-aspartate } 2 \mathrm{C}\end{array}$ & GRIN2C & 2 & 5 & 4 & 27 & 0,05 & 0,04 \\
\hline 38 & GCCTGTGGTG & Lymphocyte antigen 6 complex, locus $\mathrm{H}$ & $L Y 6 H$ & 4 & 3 & 4 & 29 & 0,05 & 0,02 \\
\hline 39 & GGGGTGCTGT & Dynamin 1 & DNM1 & 8 & 5 & 32 & 223 & 0,05 & 0,00 \\
\hline 40 & TCGGGGCCCC & Complexin 1 & $C P L X 1$ & 4 & 5 & 17 & 122 & 0,05 & 0,00 \\
\hline 41 & TCTATTAATA & Myelin basic protein & $M B P$ & 6 & 5 & 41 & 308 & 0,05 & 0,00 \\
\hline 42 & TGAGGTTATC & $\begin{array}{l}\text { Guanine nucleotide binding protein (G protein), } \\
\text { gamma } 3\end{array}$ & GNG3 & 4 & 5 & 6 & 41 & 0,05 & 0,00 \\
\hline 43 & TGGAGTGAAA & SH3-domain GRB2-like 2 & SH3GL2 & 6 & 5 & 9 & 59 & 0,05 & 0,00 \\
\hline 44 & TGGCTGGAAG & Phosphoinositide-binding protein PIP3-E & PIP3-E & 4 & 5 & 4 & 26 & 0,05 & 0,05 \\
\hline 45 & TACССТСТCA & $\begin{array}{l}\text { ATPase, } \mathrm{Na}^{+} / \mathrm{K}^{+} \text {transporting, alpha } 3 \\
\text { polypeptide }\end{array}$ & $A T P 1 A 3$ & 2 & 5 & 5 & 42 & $0,, 04$ & 0,00 \\
\hline 46 & AAATAAAGCC & Gamma-aminobutyric acid (GABA) A receptor, & $G A B R D$ & 2 & 5 & 5 & 42 & 0,04 & 0,00 \\
\hline 47 & ACAACACTAC & RAB3A, member RAS oncogene family & $R A B 3 A$ & 7 & 5 & 15 & 115 & 0,04 & 0,00 \\
\hline
\end{tabular}




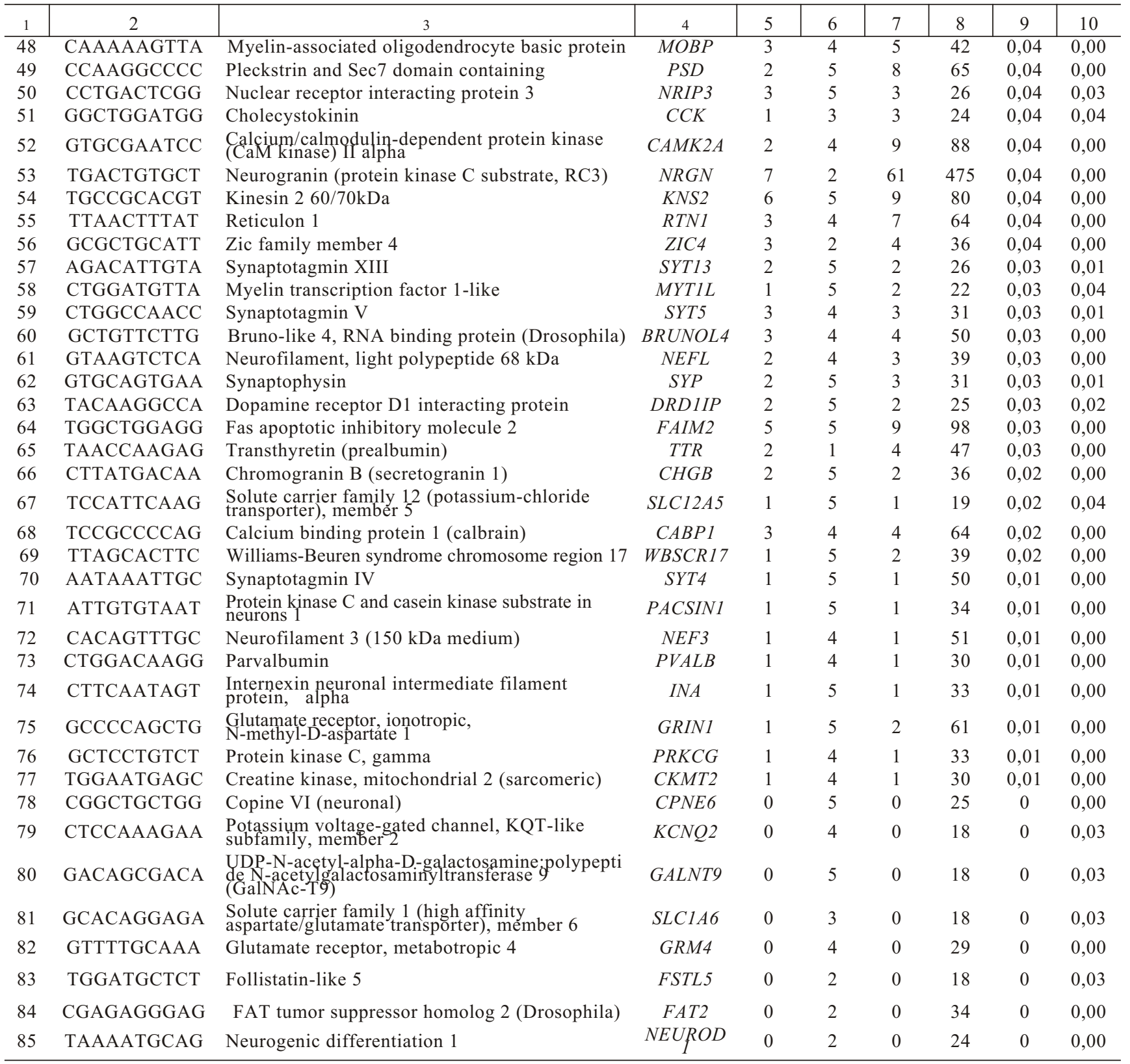

STBXP1 mRNA content is very low in both NB and glioblastomas. Most likely, the difference in gene expression levels in individual tumour and NB samples reflects heterogeneity of biological properties of tumours as well as individual polymorphism.

Noteworthy is the fact that the biggest number of genes is expressed in brain compared to any other tissue $[10,11]$. And only concerning small number of genes, for instance, $M B P, D N M 1$, and $N R G N$, the abundance of their mRNA in general pool of mRNA is sufficient for Northern hybridisation analysis. To determine the contents of rare transcripts in tumour cells, we applied semi-quantitative RT-PCR. RT-PCR results for FAT2 generally correlated with those of SAGE. PCR product was detected in 5 of 7 NB samples and 6 of 14 samples of glioblastomas (Fig.3).

RT-PCR results for CPNE6 were in very good correlation with those of SAGE, i.e. PCR product was dis- 
Table 2

Distribution of levels of gene expression at each stage of astrocytoma development

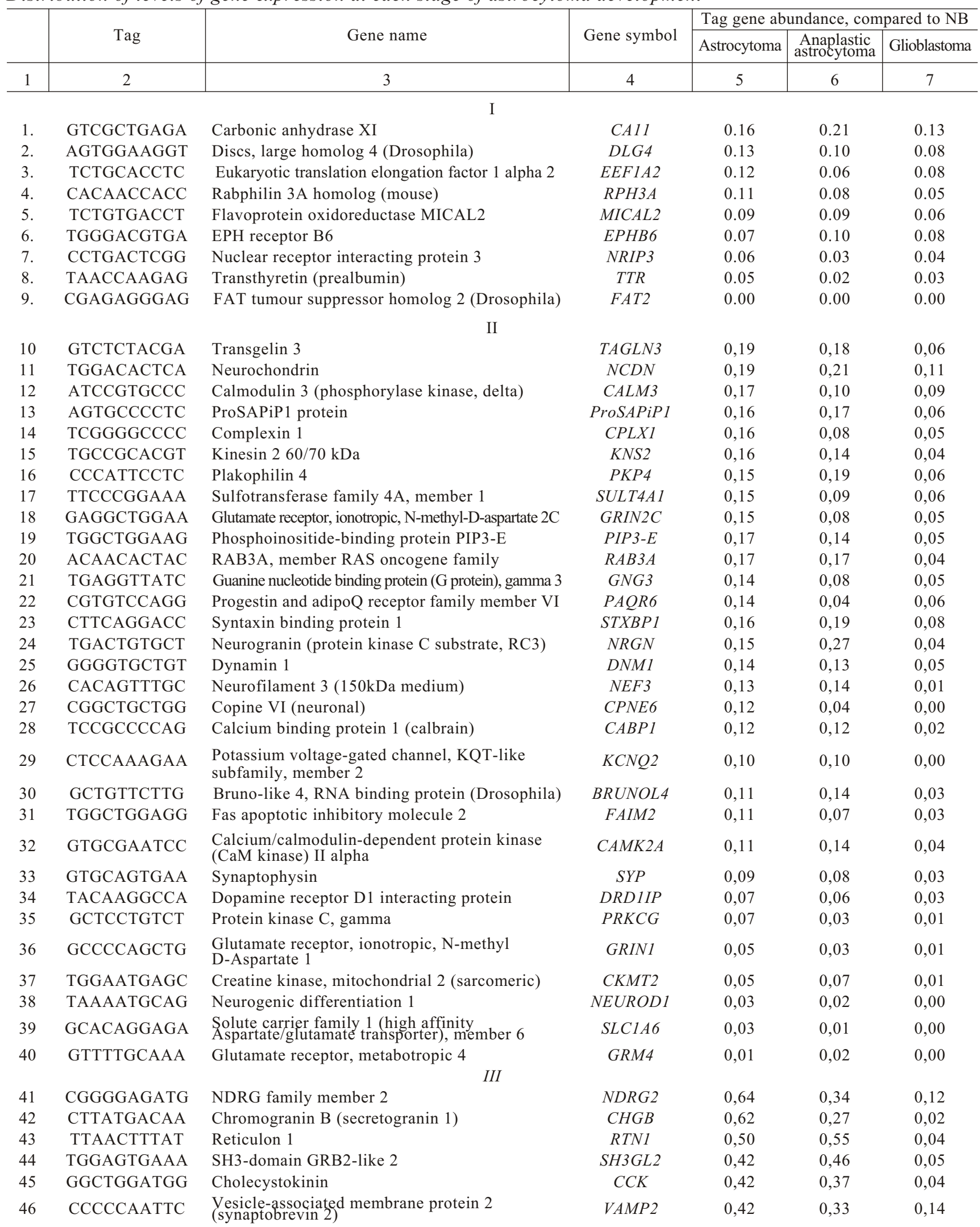




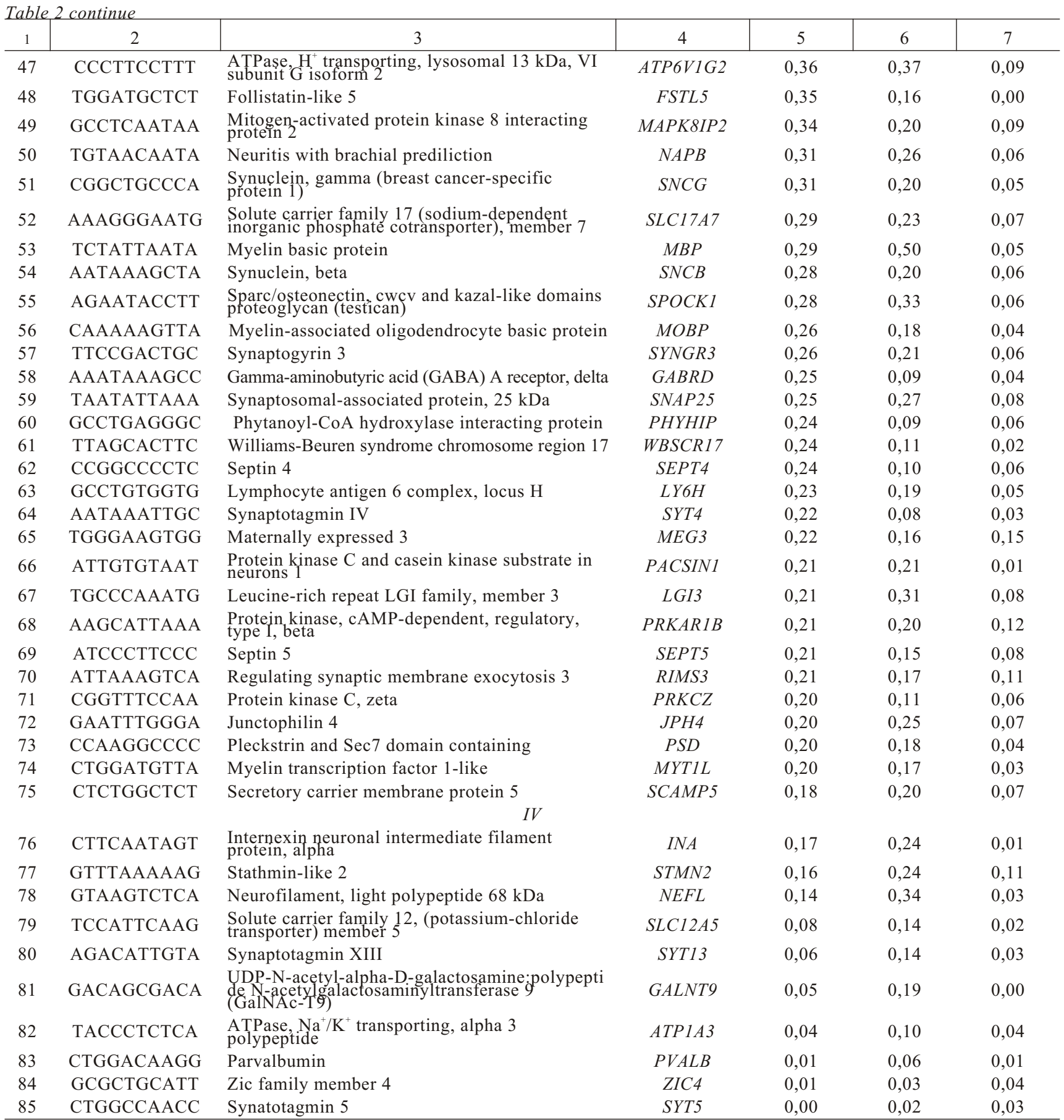

covered in 8 of $9 \mathrm{NB}$ samples and 4 of 10 samples of glioblastomas, while in one glioblastoma only, the level of gene expression was the same as in NB samples and to be significantly lower in other three GB samples (Fig.4). RT-PCR did not confirm the results of SAGE for GRM4 - PCR product was discovered in 1 of $11 \mathrm{NB}$ samples and 3 of 9 samples of glioblastoma.
The changes in transcription activity of genes, obtained in this sort of comparison, are generally of different genesis, i.e. they may cause malignant transformation of cells, they may be the consequences of this transformation or they may not have any direct relation to the latter. Certainly, this sort of grouping is rather subjective, minding that the majority of protein prod- 

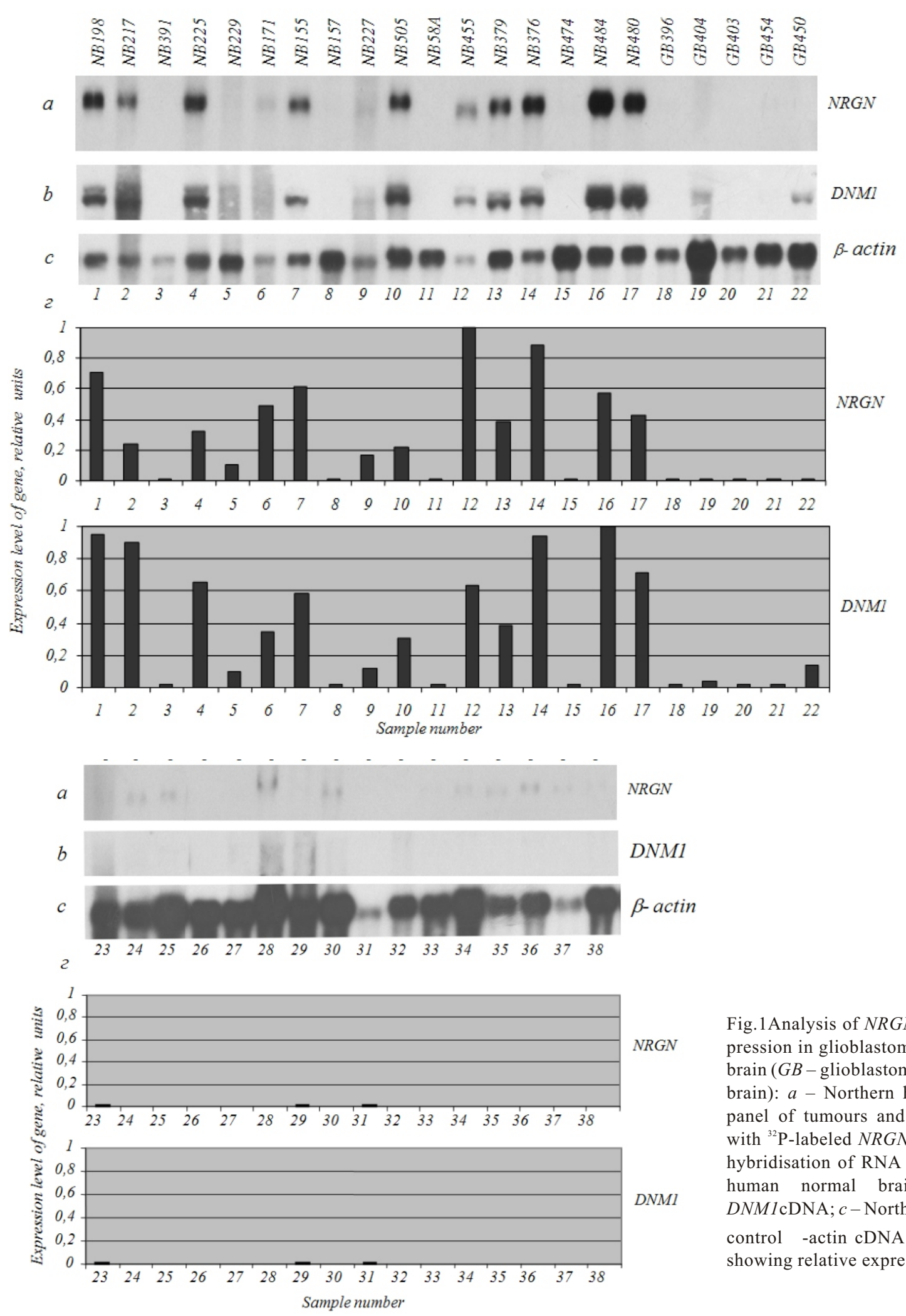

NRGN

Fig.1 Analysis of $N R G N$ and DNM1 gene expression in glioblastomas and human normal brain ( $G B$ - glioblastoma; $N B$-human normal brain): $a$ - Northern hybridisation of RNA panel of tumours and human normal brain with ${ }^{32} \mathrm{P}$-labeled $N R G N$ cDNA; $b$ - Northern hybridisation of RNA panel of tumours and human normal brain with ${ }^{32} \mathrm{P}$-labeled DNM1cDNA; $c$ - Northern hybridisation with control $\beta$-actin cDNA probe; $d$ - bar graph showing relative expression level of gene 


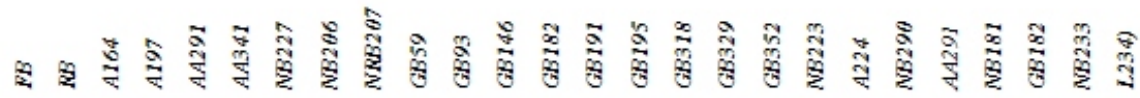
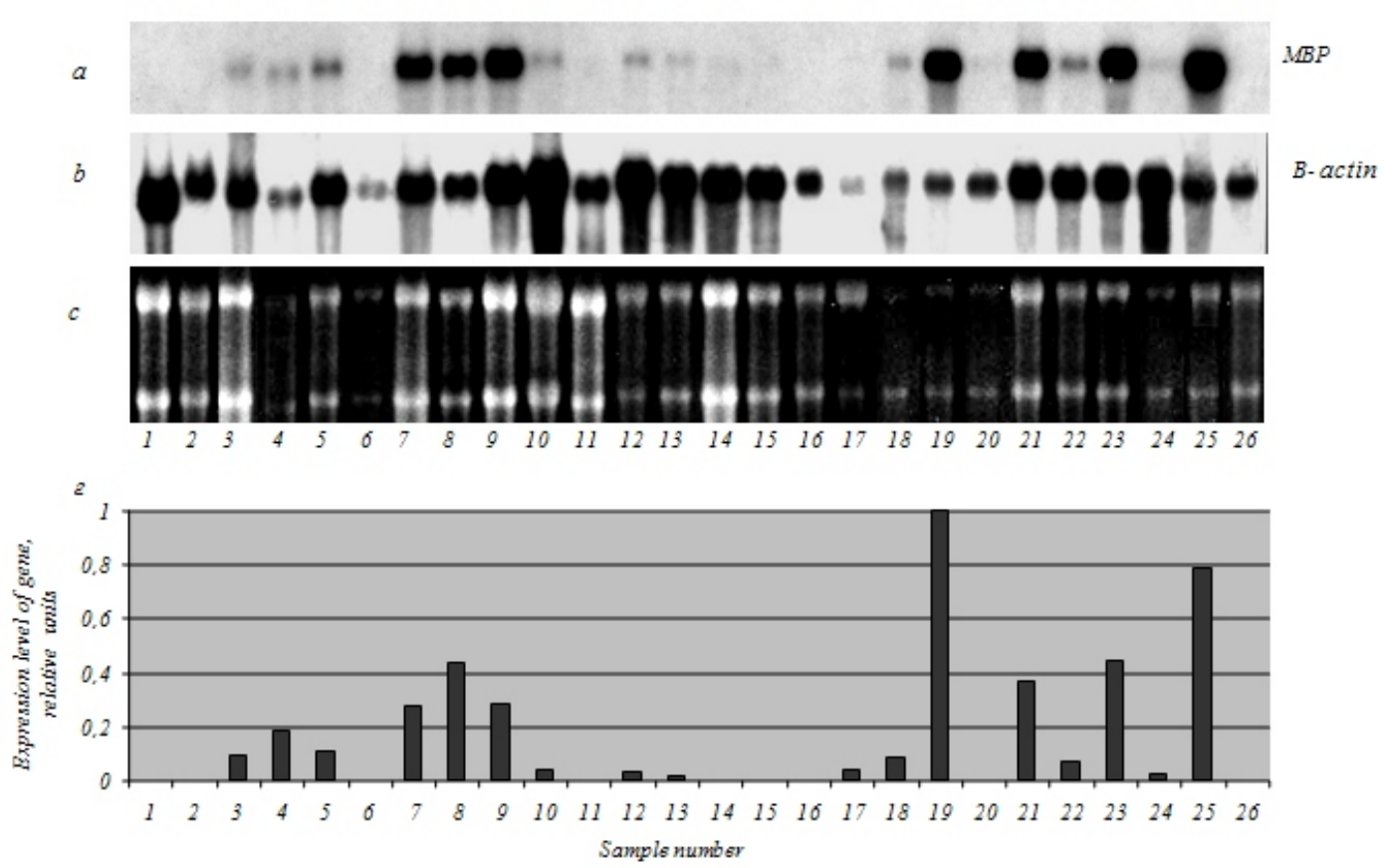

Fig.2 Analysis of $M B P$ gene expression in tumours and human normal brain ( $G B$ - glioblastoma; $R B$ - rat brain; $A-$ astrocytoma, $A A-$ anaplastic astrocytoma; $N B$ - normal human brain; $N R B$ - neuroblastoma, $G B$-glioblastoma; $L$ - lymphoma): $a$-Northern hybridisation of RNA panel of tumours and human normal brain with ${ }^{32} \mathrm{P}$-labeled $M B P$ cDNA; $b$ - Northern hybridisation with control $\beta$-actin cDNA probe; $c$ - ethidium bromide stained agarose gel; $d$-diagram of relative level of gene expression

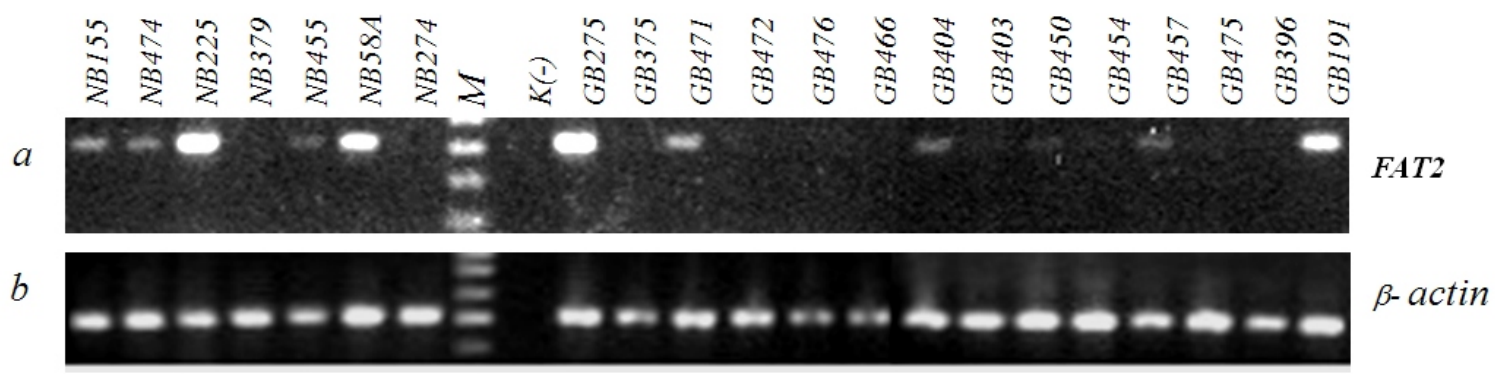

Fig. 3 Semi-quantitative PCR-analysis of FAT2 gene expression in glioblastomas and human normal normal brain ( $G B$ - glioblastoma; $N B$ normal human brain): $a$ - electrophoresis of PCR products with primers for $F A T 2 ; b$ - electrophoresis of PCR products with primers for beta-actine

ucts of these genes are polyfunctional and the question of which of the functions are involved (if involved at all) in the formation of astrocytomas remains open.

Gene symbol was used to identify genes in CGAP database

(http://cgap.nci.nih.gov/SAGE/AnatomicViewer) and to determine potential functions of their protein products in different databases and publications for each gene, which allowed grouping genes with similar functions (Table 3). As it has been expected, the major part of genes with decreased level of expression in gliomas encode the proteins, participating in neurogenesis, synaptic transmission, formation of nerve ensheatment and neurofilament. The decrease in levels of gene expression of the aforementioned functional groups may be trustworthily refer to the third class of expression 

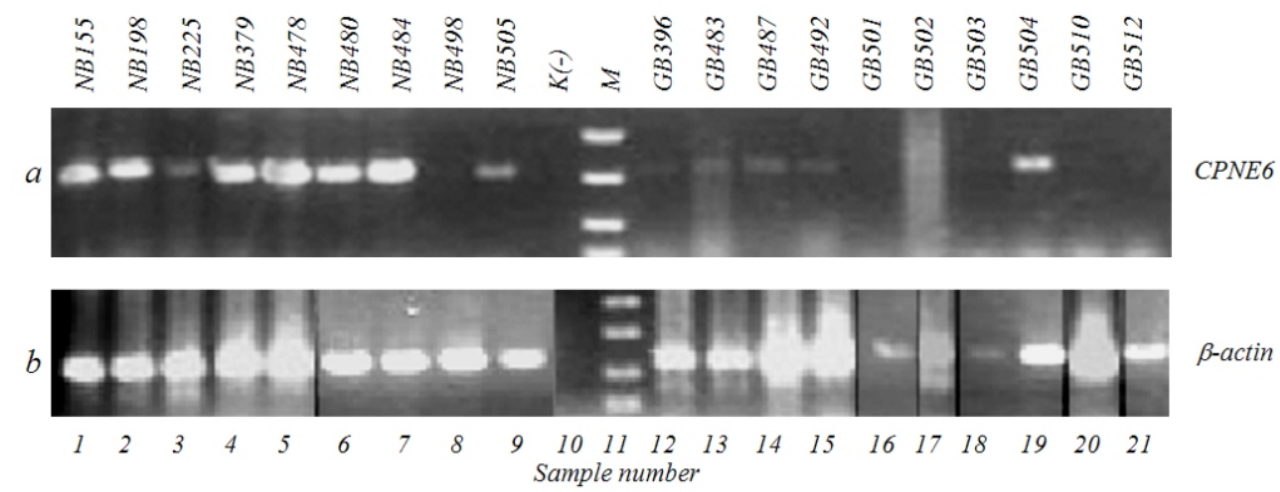

Fig.4 Analysis of CPNE6 in glioblastomas and normal human brain using with semi-quantitative RT-PCR ( $G B$ - glioblastoma; $N B$ - normal human brain): $a$ - electrophoresis of PCR products obtained with primers for CPNE6; $b$ - electrophoresis of PCR products obtained with primers for $\beta$-actin

changes, although, there is a possibility of their intermediate participation in tumour development. These genes are expressed predominantly in the neural cells, relative quantity of which decreases in glial tumours. Therefore, the decrease in content of such mRNA possibly reflects the decrease in the percentage of neural cells in astrocytomas. There have been no data of their involvement in the carcinogenesis for more than half of reviewed genes, belonging to these groups. However, some genes may be used for the characterisation of malignant neoplasmas and may have prognostic potential.

A significant number of genes with decreased expression in glioblastoma encode the products, involved in transporter activity and cell signal transduction (Table 3). Molecular distunbances of signal transduction are known to play the important role in the development of glial tumours. Some expression changes, discovered in the present work, were earlier found in human brain cells for the following genes: $C C K$, encoding cholecystokinin (brain/gut peptide); EPHB6, encoding ephrin B6 receptor and neurogranin gene $N R G N$, which encodes protein kinase substrate $\mathrm{C}$.

Cholecystokinin is involved in performance of numerous functions in the brain, in particular, feeding behaviour, anxiety and memory. Brain CCK mRNA levels are low before birth, but increase markedly shortly after birth and reach adult like patterns of expression three weeks after birth during the final maturation of the central nervous system. In the adult, several substances induce neuronal CCK mRNA expression via activation of transcription factors binding to regulatory elements in the CCK promoter [13].

Though gastrin, cholecystokinin-related protein, was demonstrated to influence the growth and mobility of glioblastoma cells [14], yet in gliomas there were no evidences of cholecystokinin receptor products [15]. Immunohistochemical analysis revealed the lower content of cholecystokinin in malignant astrocytomas, compared to well-differentiated astrocytomas (malignancy grades I-II) [16]. This protein was detected in neuronal cells, preserved in 7 investigated supra-tentorial anaplastic astrocytomas, however, it was absent in other gliomas -3 diffuse astrocytomas and 8 glioblastomas [17] as well as in subependymal giant cell astrocytomas [18]. Inactivation of $C C K$ expression is likely to take place at the level of transcription or translation, or post-translational processing during malignant progression of gliomas. It is confirmed by our SAGE results - CCK gene tags are present in 1 of 9 glioblastoma SAGE-libraries only. In vivo experiments show that cholecystokinin may induce signalling processes with assistance of protein kinase $\mathrm{C}$ in rat glioma C6 cell line, for which the expression of CCKB-type of receptors has been identified [19]. Cholecystokinin stimulates the growth of $\mathrm{C} 6$ cells, activating isoenzymes $\beta 1, \beta 2, \gamma$, and $\zeta$ of $C$ protein kinase [20].

Ephrin receptors and their ligands play the role of mediators in numerous processes of development, in nervous system, in particular. Based on the structure and sequence relations, ephrins can be classified into class A (EFNA), which are anchored to membrane with 
Potential suppressor genes of glial tumours, grouped

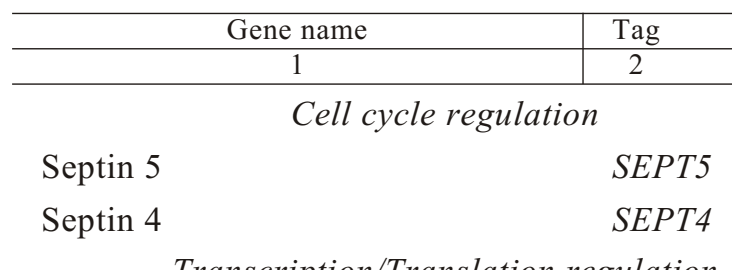

\section{Transcription/Translation regulation}

Bruno-like 4, RNA binding

protein (Drosophila)

BRUNOL4

Eukaryotic translation elongation factor 1 alpha

EEF $1 A 2$

Myelin transcription factor 1-like

MYT1L

Neurogenic differentiation 1

NEUROD1

Neurogenesis

Copine VI (neuronal)

Discs, large homolog 4

(Drosophila)

CPNE6

Lymphocyte antigen 6 complex, locus

$D L G 4$

$L Y 6 H$

Myelin-associated

olygodendrocyte basic protein

MOBP

Neurogranin

$N R G N$

Transgelin 3

TAGLN3

Nerve ensheatment

Myelin basic protein

$M B P$

Myelin-associated

olygodendrocyte basic protein Neurofilament

Internexin neuronal intermediate

filament protein, alpha

$N E F 3$

Neurofilament 3 (150kDa medium)

$N E F L$

Neurofilament, light polypeptide $68 \mathrm{kDa}$

Synaptic transmission

Calcium/calmodulin-dependent protein kinase (CaM kinase) II

CAMK2A

Complexin 1

CPLX1

Copine VI (neuronal)

CPNE6

Discs, large homolog 4

(Drosophila)

$D L G 4$

Dopamine receptor D1 interacting protein

DRDIIP

Gamma-aminobutyric acid

(GABA) A receptor, delta

GABRD

Glutamate receptor, ionotropic,

$\mathrm{N}$-methyl D-aspartate 1

GRIN1

Glutamate receptor, ionotropic,

$\mathrm{N}$-methyl D-aspartate 2C

GRIN2C

Glutamate receptor, metabotropic $4 \quad$ GRM4

Myelin basic protein

$M B P$

Myelin-associated

olygodendrocyte basic protein

$M O B P$

Neuronal pentraxin 1
NPTX1
Solute carrier family 1 (high

affinity aspartate/glutamate

transporter), member 6

Solute carrier family 12 ,

member 5 -chloride transporter)

Synaptosomal-associated protein, $25 \mathrm{kDa}$

Synaptogyrin 3

Synaptophysin

Synaptotagmin V

Synaptotagmin XIII

Syntaxin binding protein 1

SLC1A6

SLC12A5

SNAP25

SYNGR3

$S Y P$

SYT53

SYT13

STXBP1

Transporter activity

ATPase, $\mathrm{Na}+/ \mathrm{K}+$ transporting,

alpha 3 polypeptide

ATP1A3

ATPase, $\mathrm{H}+$ transporting,

lysosomal $13 \mathrm{kDa}$, V1 subunit $\mathrm{G}$ isoform 2

ATP6V1G2

Potassium voltage-gated channel,

KQT-like subfamily, member 2

Solute carrier family 17

KCNQ2

Protein kinase $\mathrm{C}$ and casein kinase substrate in neurons 1

SLC17A7

Synaptotagmin IV

PACSIN1

Synaptotagmin XIII

SYT4

SYT13

Vesicle-associated membrane

protein (VAMP)/synaptobrevin

Transthyretin (prealbumin)

VAMP2

Phosphoinositide-binding protein

Neuritis with brachial prediliction

RAB3A, member RAS oncogene family

Rabphilin 3A homolog (mouse)

TTR

PIP3-E

$N A P B$

$R A B 3 A$

RPH3A

SCAMP 5

Dynamin 1

Endocytosis

Protein kinase $\mathrm{C}$ and casein kinase substrate in neurons 1

DNM1

PACSIN1

Signal transduction

Calcium binding protein 1

(calbrain)

$C A B P 1$

$C C K$

Discs, large homolog 4

$D L G 4$

(Drosophila)

EPHB6

EPH (Ephrin) receptor B6

GABRD

Gamma-aminobutyric acid (GABA)

A receptor, delta

Guanine nucleotide binding protein (G protein), gamma 3

GNG3

Mitogen-activated protein kinase 8 interacting protein 2

MAPK8IP 2

Neurogranin

$N R G N$ 


\begin{tabular}{|c|c|c|c|}
\hline 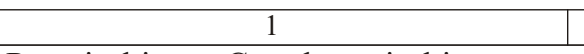 & 2 & 1 & 2 \\
\hline $\begin{array}{l}\text { Protein kinase } \mathrm{C} \text { and casein kinase } \\
\text { substrate in neurons } 1\end{array}$ & PACSIN1 & $\begin{array}{l}\text { Solute carrier family } 1 \text { (high affinity } \\
\text { aspartate/glutamate transporter), member } 6\end{array}$ & SLC1A6 \\
\hline $\begin{array}{l}\text { Protein kinase, cAMP-dependent, } \\
\text { regulatory, type I, beta }\end{array}$ & PRKARIB & Septin 4 & SEPT4 \\
\hline Protein kinase $\mathrm{C}$, gamma & PRKCG & Hormonal activity & \\
\hline Protein kinase $\mathrm{C}$, zeta & PRKCZ & Chromogranin B (secretogranin 1) & $C H G B$ \\
\hline Plakophilin 4 & PKP4 & Transthyretin (prealbumin) & $T T R$ \\
\hline Reticulon 1 & RTN1 & Ion binding & \\
\hline SH3-domain GRB2-like 2 & SH3GL2 & Follistatin-like 5 & FSTL5 \\
\hline $\begin{array}{l}\text { Apoptosis } \\
\text { Fas apoptotic inhibitory }\end{array}$ & FAIM2 & Parvalbumin & $P V A L B$ \\
\hline Septin 4 & SEPT4 & Carbonic anhydrase 11 & CA11 \\
\hline $\begin{array}{l}\text { Neurogranin } \\
\text { Creatine kinase mitochondrial } 2\end{array}$ & $\begin{array}{l}N R G N \\
C K M T 2\end{array}$ & $\begin{array}{l}\text { Leucine-rich repeat LGI family, } \\
\text { member } 3\end{array}$ & $L G I 3$ \\
\hline GTPase activity & & Junctophilin 4 & JPH4 \\
\hline Dynamin 1 & DNM1 & Maternally expressed 3 & $M E G 3$ \\
\hline $\begin{array}{l}\text { Guanine nucleotide binding protein } \\
\text { (G protein), gamma } 3\end{array}$ & $G N G 3$ & $\begin{array}{l}\text { Flavoprotein oxidoreductase MICAL2 } \\
\text { Neurochondrin }\end{array}$ & $\begin{array}{l}M I C A L \\
N D C N\end{array}$ \\
\hline $\begin{array}{l}\text { RAB3A, member RAS oncogene } \\
\text { family }\end{array}$ & $R A B 3 A$ & $\begin{array}{l}\text { NDRG family member } 2 \\
\text { Nuclear receptor interacting protein } 3\end{array}$ & $\begin{array}{l}N D R G \\
N R I P 3\end{array}$ \\
\hline Septin 5 & SEPT5 & $\begin{array}{l}\text { Progestin and adipoQ receptor } \\
\text { family member V1 }\end{array}$ & PAQR6 \\
\hline Cell adhesion/motility & SEPT4 & $\begin{array}{l}\text { Phytanoyl-CoA hydroxylase } \\
\text { interacting protein }\end{array}$ & PHYHIP \\
\hline $\begin{array}{l}\text { FAT tumour suppressor homolog } 2 \\
\text { (Drosophila) } \\
\text { Lipid metabolism }\end{array}$ & FAT2 & $\begin{array}{l}\text { ProSAPiP } 1 \text { protein } \\
\text { Pleckstrin and Sec } 7 \text { domain containing } \\
\text { Synuclein, beta }\end{array}$ & $\begin{array}{l}\text { ProSaPiP1 } \\
\text { PSD } \\
\text { SNCB }\end{array}$ \\
\hline Synuclein, beta & $S N C B$ & $\begin{array}{l}\text { Synuclein, gamma (breast } \\
\text { cancer-specific protein 1) }\end{array}$ & $S N C G$ \\
\hline $\begin{array}{l}\text { Sulfotransferase family } 4 \mathrm{~A} \text {, } \\
\text { member } 1 \\
\text { Cytosceleton related }\end{array}$ & SULT4A1 & $\begin{array}{l}\text { Sparc/osteonectin, cwcv and } \\
\text { kazal--like domains proteoglycan } \\
\text { (testican) }\end{array}$ & $S P O C K$ \\
\hline Kinesin $260 / 70 \mathrm{kDa}$ & KNS2 & Stathmin-like 2 & STMN2 \\
\hline $\begin{array}{l}\text { Septin } 5 \\
\text { Membrane protein } \\
\text { UDP-N-acetyl-alpha-P-galactosamine } \\
\text { : polypeptide N-acetylgalactosaminyl } \\
\text {-transferase 9 (GalNAc-T9) }\end{array}$ & GALNT9 & $\begin{array}{l}\text { Sulfotransferase family } 4 \mathrm{~A}, \\
\text { member } 1 \\
\text { Zic family member } 4 \\
\text { Williams-Beuren syndrome } \\
\text { chromosome region } 17\end{array}$ & $\begin{array}{l}\text { SULT4A1 } \\
\text { ZIC4 } \\
\text { WBSCR } 17\end{array}$ \\
\hline
\end{tabular}

glycosylphosphatidylinositol linkage, and class B (EFNB), which are transmembrane proteins. Ephrin receptors are divided into two groups, on the basis of similarity of amino acid sequences of their extra-cellular domains and affinity in relation towards binding of A and B ephrins. Ephrin receptors present the largest sub-group in the family of tyrosine kinases. Receptors participate in the process of development of nervous system, such as formation of boundaries, vasculogenesis, and cell migration [21]. The expression of one of them, EphB2, in gliomas cells was discovered to result in decrease in cell adhesion and increase in cell invasion [22]. Besides, R-Ras plays the key role in regulation of integrins activity by this receptor via association and subsequent phosphorylation. Inhibition of expression of endogenic R-Ras with small interfering RNA (siRNA) abolished EphB2 effect on cell adhesion, proliferation and invasion in brain. The degree of R-Ras phosphorylation is positively correlated with degree of EphB2 phosphorylation in glioblastoma cells. These results demonstrate the possibility of therapeutic influencing on signalling pathway EphB2/R-Ras [22]. Ephrin receptor B6, encoded by $E P H B 6$, does not show kinase activity, specific to the majority of tyrosine kinase receptors, and binds B-ephrins. Decreased expression level of EPHB6 was 
discovered in prostate [23], breast [24], and melanoma cancer cells [25]. The reason of inactivation of EPHB6 was determined to be the increase in the level of methylation of its promoter. Demethylation of this promoter restores the normal level of gene expression [24]. Expression of EPHB6 is one of favourable factors for prognosis of neuroblastomas [26]. The increase in the level of EPHB6 transcription was determined in neuroblastoma cell line after transfection with antisense cDNA MIF (macrophage migration inhibition factor). The result of this transfection was $80 \%$ decrease in cell growth of neuroblastomas, as well as $90 \%$ decrease (compared to the control) in tumour growth and the level of metastasis in mice, injected with these transfectants [27].

Human $N R G N$ (neurogranin; protein kinase C substrate; $R C 3$ ) is the homologue of neurospecific gene of rat $R C 3 /$ neurogranin. This gene encodes post-synaptic substrate of protein kinase $\mathrm{C}$, which binds calmodulin at the absence of calcium [28]. Neurogranin was discovered to be possible proapoptotic factor, participating in induction of T-cells apoptosis upon elimination of interleukin-2 due to the increase in inner-cellular $\mathrm{Ca}^{2+}$ concentration [29]. $N R G N$ is identified among genes, which are regulated by gene of early growth response EGR1 in prostate cancer line cells [30]. The authors suppose that overexpression of EGRl may be related to neuroendocrine differentiation, which often accompanies the progression of prostate cancer. The decrease in $N R G N$ expression in glioblastoma (along with 44 other genes) was revealed comparing the profiles of gene expression in glioblastoma and NB using cDNA microarrays, containing 25344 genes, and confirmed by semi-quantitative RT-PCR [31]. Possibly, the decreased $N R G N$ expression is associated with inhibition of apoptosis in glioblastomas or is the reflection of decrease in number of neural cells in tumours or their weakened functioning.

Inactivation of ion transport genes in glial tumours has been discovered earlier. Thus, Markert et al. [8] determined the decreased expression of several genes, encoding ion transport proteins, particularly subunits GRIN1 and GRIN2C of NMDA receptor, during profiling of gene expression in glioblastomas by the analysis of oligonucleotide microarrays, which is in good correlation with our results.
Disorder in cell cycle regulation is one of attributes of malignant progression of astrocytomas. The disordering is mediated by the inactivation of anti-oncogenes TP53, CDKN2|p16, and $R b$ on $17 \mathrm{p}, 9 \mathrm{p}$, and $13 \mathrm{q}$ chromosomes respectively [32]. The weakened cell cycle control may be the reason of significant resistance of glioblastomas towards radio and chemotherapies [33]. The group of genes capable of regulating cell cycle includes SEPT4 and SEPT5 (Table 3), which encode septin family proteins. Immunohistochemical analysis revealed the absence of SEPT4 (ARTS) protein in normal astrocytes and the increase in its production throughout the malignancy progression [34]. The increase in expression of this gene correlates with the highest degree of apoptosis in tumours. Perhaps the presence of SEPT4 indicates the ability of tumour cells to apoptosis and may be considered as independent prognostic factor. It is also quite possible that the differences in results of protein analysis and SAGE demonstrate the difference in stability and translatability of this mRNA in normal and tumour astrocytes.

FAT2 gene tag $(M E G F 1)$ is present in neither one of SAGE-libraries of astrocytomas of II-IV malignancy degrees. This protein belongs to the family of cadherins - the group of integral membrane proteins, specific for the presence of cadherin type of repeats. Beside 34 tandem cadherin type repeats, the protein contains 2 EGF-like repeats and one laminin $\mathrm{G}$ domain $[35,36]$. It is the second identified human homologue of Drosophila FAT, which encodes tumour suppressor, important for control of cell proliferation throughout the development of Drosophila. In situ hybridisation revealed mRNA products in granular cells (small neurons) of inner external germinal layer and migrating granular cells, whereas FAT2 is not expressed in proliferating cells of outer external germinal layer [37]. Apparently FAT2 protein is responsible for cell adhesion, which controls cell proliferation and plays the important role in the development of brain.

The results, obtained in this work, confirm and supplement the data of other authors, stimulate the search for new therapeutic targets for glial tumours. The genes, expression of which was not detected in glioblastomas at all (CPNE6, KCNQ2, GALNT9, SLC1A6, GRM4, FSTL5, FAT2, and NEUROD1) are 
the most probable candidates for tumour-suppressor genes, among 85 other genes, identified with SAGE.

Therefore, in this work we identified approximately 100 genes with more than 5-fold decreased expression in astrocytic gliomas of malignancy grades II-IV. Some of them may be potential tumour suppressor genes. Abnormalities, resulting in inactivation of tumour suppressor genes, are often linked to the decrease in the level of their expression. In some tumours or cell lines there may be deletions in one or both gene copies, methylation of promoter, mutations of splicing site, nonsense-mutations or combinations of these events, which initiate preliminary termination of translation and destabilise mRNA-transcripts. Such mutations are often connected with complete absence or partial decrease in the level of expression of tumour-suppressor gene [38].

The application of SAGE allows determining similar genes and understanding their functions [39]. However, to determine the decreased levels of gene expression in tumour is the first step at the beginning of a long chain of experiments on the identification of tumour suppressor genes. The second stage includes functional research in order to understand the connection between molecular events and their interactions. Further characterisation will allow using these genes for diagnostics and medical prognostics, antitumour therapy and molecular classification of neoplasms.

The work was supported by National Academy of Sciences of Ukraine in the framework of the programmes Novel Medical-Biological Problems and Human Environment and Fundamental Bases of Genomics, Proteomics and Novel Biotechnologies, as well as by Ministry of Science and Education of Ukraine in the framework of the programme of integrated action of Ukraine and France in the field of science and technology Dnipro.

В. В. Дмитренко, О. И. Бойко, Е. А. Шостак, Н. Я. Витак, Т. В. Букреева, В. Д. Розуменко, Т. А. Мальшева, М. И. Шамаев, Ю. П. Зозуля, В. М. Кавсан

Характеристика генов со сниженной экспрессией в глиомах человека - потенциальных опухолесупрессорных генов

Резюме

В результате сравнения профилей экспрессии генов в нормальном головном мозге и глиобластоме с использованием базы данных серийного анализа генной экспрессии (Serial Analysis of Gene Expression, SAGE) выявлены 129 генов с более чем пятикратным изменением уровня экспрессии $(P \leq 0,05)$ в глиобластоме, из которых 85 генов - со сниженной экспрессией. В диффузной и анапластичной астроцитомах количество генов со сниженной в пять раз экспрессией меньше. Лишь для девяти генов пятикратное снижение экспрессии происходит в диффузных астроцитомах $и$ выявляется приблизительно на таком же уровне в анапластичных астроиитомах $u$ в глиобластомах. Для подавляюшего большинства инактивированных генов уровень экспрессии снижается в диффузных астроцитомах $u$ последовательно уменьшается на дальнейших стадиях злокачественной прогрессии астроцитом, причем 6 глиобластомах - наиболее злокачественных проявлениях глиальных опухолей - экспрессия отдельных генов очень низкая или совсем отсутствует. Нозерн-гибридизаџия и ОТ-ПЦР (обратная транскрипиия-полимеразная цепная реакция) подтвердили сниженную экспрессию в глиобластомах произвольно отобранных генов. Некоторые гены, описанные в этой работе, могут кодировать опухолевые супрессоры и их сниженная экспрессия, очевидно, играет важную роль в инициации и прогрессии глиом человека.

Ключевые слова: глиома, астроиитома, глиобластома, сниженная экспрессия генов, потенциальные опухолесупрессорные гены.

\section{REFERENCES}

1. Loging W.T., Lal A., Siu I.M., Loney T.L., Wikstrand C.J., Marra M.A., Prange C., Bigner D.D., Strausberg R.L., Riggins G.J. Identifying potential tumour markers and antigens by database mining and rapid expression screening // Genome Res. - 2000. - 10. - P.1393-1402.

2. V. Kavsan, K. Shostak, V. Dmitrenko, Y. Zozulya, V. Rozumenko, J. Demotes-Mainard. Characterization of genes with significantly increased expression in human glioblastomas // Цитология и генетика. - 2005. - 39, №6. C. $37-49$.

3. Дмитренко В.В., Бойко О.І., Шостак К.О., Симиренко О.С., Букреєва Т.В., Розуменко В.Д., Малишева Т.А., Шамаєв М.І., Зозуля Ю.П., Кавсан В.М. Надекспресія генів на різних стадіях розвитку астроцитарних гліом // Біополімери і клітина. - 2006. - 22, №1 - - С.38-48.

4. Chomczynski P., Sacchi N. Single step method of RNA isolation by acid guanidinium thiocyanate-phenol-chloroform extraction // Anal. Biochem. - 1987. - 162. - P. 156-159.

5. Rae F.K., Stephenson S.A., Nicol D.L., Clements J.A. Novel association of a diverse range of genes with renal cell carcinoma as identified by differential display // Int. J. Cancer. 2000. - 88. - P.726-732.

6. Kavsan V., Shostak K., Dmitrenko V., Chausovskiy T., Zozulya Y., Demotes-Mainard J. Peculiarities of molecular events in human glial tumours revealed by serial analysis of gene expression (SAGE) // Exp. Oncol. - 2004. - 26, №3. P.196-204.

7. Lal A., Lash A.E., Altschul S.F., Velculescu V., Zhang L., McLendon R.E., Marra M.A., Prange C., Morin P.J., Polyak

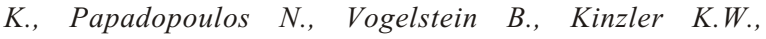
Strausberg R.L., Riggins G.J. A public database for gene ex- 
pression in human cancers // Cancer Res. - 1999. - 59. P.5403-5407.

8. Markert J.M., Fuller C.M., Gillespie G.Y., Bubien J.K., McLean L.A., Hong R.L., Lee K., Gullans S.R., Mapstone T.B., Benos D.J. Differential gene expression profiling in human brain tumours // Physiol. Genomics. - 2001. - 5. P.21-33.

9. Ljubimova JY, Lakhter A, Loksh A, Yong WH, Riedinger MS, Miner JH, Sorokin ML, Ljubimov AV, Black $K L$. Overexpression of a4 chain-containing laminins in human glial tumours identified by gene microarray analysis // Cancer Res. - 2001. - 61. - P. 5601-5610.

10. Ryffel G.U., McCarthy B.J. Complexity of cytoplasmic RNA in different mouse tissues measured by hybridization of polyadenylated RNA to complementary DNA // Biochemistry. - 1975. - 14, №7. - P.1379-1385.

11. Croizat B., Berthelot F., Felsani A., Gros F. Complexity of polysomal polyadenylated RNA in mouse whole brain and cortex // FEBS Lett. - 1979. - 103, №1 - - P.138-143.

12. Ekstrand A.J., Longo N., Hamid M.L., Olson J.J., Liu L., Collins V.P., James C.D. Functional characterization of an EGF receptor with a truncated extracellular domain expressed in glioblastomas with EGFR gene amplification // Oncogene. 1994. - 9. - P.2313-2320.

13. Hansen T.V., Nielsen F.C. Regulation of neuronal cholecystokinin gene transcription // Scand. J. Clin. Lab. Invest. Suppl. - 2001. - 234. - P.61-67.

14. Camby I., Salmon I., Danguy A., Pasteels J.L., Brotchi J., Martinez J., Kiss R. Influence of gastrin on human astrocytic tumour cell proliferation // J. Natl. Cancer Inst. - 1996. - 88, №9. - P.594-600.

15. Lefranc F., Chaboteaux C., Belot N., Brotchi J., Salmon I., Kiss $R$. Determination of RNA expression for cholecystokinin/gastrin receptors (CCKA, CCKB and CCKC) in human tumours of the central and peripheral nervous system // Int. J. Oncol. - 2003. - 22, №1 - - P.213-219.

16. Allen J.M., Hoyle N.R., Yeats J.C., Ghatei M.A., Thomas D.G., Bloom S.R. Neuropeptides in neurological tumours // J. Neurooncol. - 1985. - 3, №3. - P.197-202.

17. Przedborski S., Goldman S., Schiffmann S.N., Vierendeels G., Depierreux M., Levivier M., Hildebrand J., Vanderhaeghen J.J. Neuropeptide Y, somatostatin, and cholecystokinin neurone preservation in anaplastic astrocytomas // Acta Neuropathol. - 1988. - 76, №5. P.507-510.

18. Lopes M.B., Altermatt H.J., Scheithauer B.W., Shepherd C.W., VandenBerg S.R. Immunohistochemical characterization of subependymal giant cell astrocytomas // Acta Neuropathol. - 1996. - 91, №4. - P.368-375.

19. Kaufmann R., Schoneberg T., Lindschau C., Haller H., Ott T. Cholecystokinin induced signaling in rat glioma C6 cells // Neuropeptides. - 1995. - 29, №5. - P.251-256.

20. Kaufmann R., Schafberg H., Zieger M., Henklein P., Nowak $G$. Protein kinase $\mathrm{C}$ is involved in cholecystokinin octapeptide-induced proliferative action in rat glioma C6 cells // Neuropeptides. - 1998. - 32, №2. - P.185-189.

21. Knoll B., Drescher U. Ephrin-As as receptors in topographic projections // Trends Neurosci. - 2002. - 25, №3. P.145-149.

22. Nakada M., Niska J.A., Tran N.L., McDonough W.S., Berens $M . E$. EphB2/R-Ras signaling regulates glioma cell adhesion, growth, and invasion // Am. J. Pathol. - 2005. - 167, №2. P.565-576.
23. Fox B.P., Tabone C.J., Kandpal R.P. Potential clinical relevance of Eph receptors and ephrin ligands expressed in prostate carcinoma cell lines // Biochem. Biophys. Res. Commun. - 2006. - 342, №4. - P.1263-1272.

24. Fox B.P., Kandpal R.P. Transcriptional silencing of EphB6 receptor tyrosine kinase in invasive breast carcinoma cells and detection of methylated promoter by methylation specific PCR // Biochem. Biophys. Res. Commun. -2006. - 340, №1. - P.268-276.

25. Hafner C., Bataille F., Meyer S., Becker B., Roesch A., Landthaler M., Vogt T. Loss of EphB6 expression in metastatic melanoma // Int. J. Oncol. - 2003. - 23, №6. P.1553-1559.

26. Tang X.X., Robinson M.E., Riceberg J.S., Kim D.Y., Kung B., Titus T.B., Hayashi S., Flake A.W., Carpentieri D., Ikegaki N. Favorable neuroblastoma genes and molecular therapeutics of neuroblastoma // Clin. Cancer Res. - 2004. - 10, №17. P.5837-5844.

27. Ren Y., Chan H.M., Fan J., Xie Y., Chen Y.X., Li W., Jiang G.P., Liu Q., Meinhardt A., Tam P.K. Inhibition of tumour growth and metastasis in vitro and in vivo by targeting macrophage migration inhibitory factor in human neuroblastoma // Oncogene. - 2006. - 25, №25. P.3501-3508.

28. Prichard L., Deloulme J.C., Storm D.R. Interactions between neurogranin and calmodulin in vivo // J. Biol. Chem. - 1999. - 274, №12. - P.7689-7694.

29. Devireddy L.R., Green M.R. Transcriptional program of apoptosis induction following interleukin 2 deprivation: identification of RC3, a calcium/calmodulin binding protein, as a novel proapoptotic factor // Mol. Cell Biol. - 2003. - 23, №13. - P.4532-41.

30. Svaren J., Ehrig T., Abdulkadir S.A., Ehrengruber M.U., Watson M.A., Milbrandt J. EGR1 target genes in prostate carcinoma cells identified by microarray analysis // J. Biol. Chem. - 2000. - 275, №49. - P.38524-38531.

31. Yokota T., Kouno J., Adachi K., Takahashi H., Teramoto A., Matsumoto K., Sugisaki Y., Onda M., Tsunoda T. Identification of histological markers for malignant glioma by genome-wide expression analysis: dynein, alpha-PIX and sorcin // Acta Neuropathol. - 2006. - 111, №1. - P.29-38.

32. Louis D.N. A molecular genetic model of astrocytoma histopathology // Brain Pathol. - 1997. - 7. - P.755-764.

33. Trog D, Moenkemann H, Breipohl W, Schueller H, Schild H, Golubnitschaja $O$. Non-sufficient cell cycle control as possible clue for the resistance of human malignant glioma cells to clinically relevant treatment conditions // Amino Acids. 2006. Nov 3; [Epub ahead of print]

34. Gottfried Y, Voldavsky E, Yodko L, Sabo E, Ben-Itzhak O, Larisch $S$. Expression of the pro-apoptotic protein ARTS in astrocytic tumours: correlation with malignancy grade and survival rate // Cancer. - 2004. - 101, №11 . - P.2614-2621.

35. Nakayama M., Nakajima D., Nagase T., Nomura N., Seki N., Ohara $O$. Identification of high-molecular-weight proteins with multiple EGF-like motifs by motif-trap screening // Genomics. -1998. - 51, №1. - P.27-34.

36. Nollet F., Kools P., van Roy F. Phylogenetic analysis of the cadherin superfamily allows identification of six major subfamilies besides several solitary members // J. Mol. Biol. - 2000. -299, №3. - P.551-572.

37. Nakayama M., Nakajima D., Yoshimura R., Endo Y., Ohara $O$. MEGF1/fat2 proteins containing extraordinarily large extracellular domains are localized to thin parallel fibers of 
cerebellar granule cells // Mol. Cell Neurosci. - 2002. - 20, №4. - P.563-578.

38. Louro I.D., Bailey E.C., Ruppert J.M. Suppression subtractive hybridization for identification and functional analysis of tumour suppressor genes // Methods Mol. Biol. 2003. - 222. - P.453-462.
39. Boon K., Riggins G.J. SAGE as a strategy to isolate cancer-related genes // Methods Mol. Biol. - 2003. - 222. P.463-479.

УДК 577.21:577.214.622+616-006.484.04 Надійшла до редакції 26.12.06 